\title{
The difference of student's activities and learning outcome with problem based learning using macromedia flash and handout
}

\author{
Desi Natalia Purba *, Marini Damanik, Saronom Silaban, Lisnawaty Simatupang \\ Department of Chemistry, Universitas Negeri Medan, Medan 20221, Indonesia
}

\begin{abstract}
:
This study aimed to determine the difference of student's activities and learning outcome with PBL using macromedia flash and handout. The sample were selected using purposive sampling into experimental group 1 and experimental group 11 with 60 students. The experimental group 1 used the PBL using macromedia flash, while the experimental group 11 used the PBL using handout. The results indicated that the mean scores of student's activities and learning outcome in the experimental group 11 were significantly higher than those in the experimental group 1. Thus, there was a difference in student's activities and learning outcome. The correlation test between student's activities and learning outcome presented that the experimental group 1 rcount $>$ rtable $(0.625>0.361)$ and the experimental group 11 rcount $>$ rtable $(0.683>0.361)$, it concluded that there was a positive correlation between student's activities and learning outcome with PBL using macromedia flash and handout.
\end{abstract}

\section{Keywords:}

activities; difference; handout; macromedia flash; learning outcome; PBL

\section{Introduction}

The success of the teaching and learning process are the main things that coveted in carrying out education in school. The main part in the teaching and learning process is students and teachers, in this case, students who are the subjects of learning, not the object of learning. Therefore, the teacher-centered learning pattern should be transformed into student-centered learning (Dewi \& Utomo, 2013).

Based on observations in Senior High School 9 Medan, it was found that the student's learning outcome is still low. This is because learning process are still often dominated by teachers. In addition, the involvement of students is still low and less enthusiastic about chemistry subjects because they assume chemistry is a difficult subject. Weaknesses of the learning process and low student achievement are the causes of the low quality of education (Wasonowati et al. 2014).

The way to improve the quality of the process and learning outcome is to apply a learning model that is in accordance with the material characteristics and conditions of the students (Wasonowati et al. 2014). The use of appropriate

\footnotetext{
* Corresponding author.

desinataliapurba07@gmail.com

doi: https://doi.org/10.2 4114/jpkim.v10i3.12704
}

learning models can encourage the growth of students' joy in learning, increase motivation in doing assignments, and make it easier for students to understand the lessons, so that they achieve better learning outcome (Aunurrahman, 2012). Accuracy of the learning models can also increase student activities in the teaching and learning process (Agustina et al. 2013; Silaban, 2017).

Problem based learning (PBL) is an educational approach that uses complex, real-world problems to motivate students to identify and research the concepts and principles that they need to know to devise a solution to the problem. PBL is constructivism learning that driven by a problem and students work in teams to learn more about the problem, conduct a research, communicate to each other, apply many essential skills and enjoy the fruits of active learning (Dewi \& Utomo, 2013; Duch et al. 2001; Flynn \& Biggs, 2011; Othman et al. 2014; Hutabarat et al. 2017).

The advantages of PBL in this learning are also supported by the results of previous research. Ariyanti et al. (2015) concluded that PBL can improve students' activeness and learning achievement in stoichiometric material. Meanwhile, Tarhan \& Acar-Sesen (2013) concluded that PBL helped students to develop group solidarity, searching and learning skills, learning achievement increased significantly from 
the first to last PBL activities. The results reflected the effects of PBL on students' social and group working skills as mentioned in the other researches.

The use of learning media in the teaching and learning process can generate new desires and interests, generate motivation and stimulation of learning activities, and bring psychological effects to students (Arsyad, 2009). Macromedia flash is a learning media that uses computers to deliver subject matter. Macromedia Flash can create a fun learning process because the material delivered is accompanied by animations that can be learned with an easy-to-understand path (Nuryanto et al. 2015). While handout is learning material that is very concise and sourced from the literature relevant to the basic competencies to facilitate students while following the learning process and be able to overcome the limitations of time allocation (Adi et al. 2014).

Mawarni et al. (2015) showed that peer tutoring learning with Macromedia Flash animation and handout on solubility product constant can improve achievement in cognitive aspects. According to the research by Wijaya et al. (2017), there is a difference of average improvement in student achievement and interest in experimental groups using macro flash-based digital media with a control group that does not use media. Based on this description, the researcher compared the use of Macromedia Flash and handout which are expected to improve student activities and outcome.

\section{Materials and Methods}

This study was conducted with sample of 60 students from two classes in Senior High School 9 Medan, Indonesian. There were experimental group $\mathrm{l}$ ( $\mathrm{nl}=30$ students) and experimental group Il (n2=30 students), which were selected using purposive sampling. Students in the experimental group 1 were taught through PBL using Macromedia flash, while the experimental group II were taught through PBL using handout.

The test instrument is an objective test (multiple choice questions) that will be standardized and adjusted to the research topic. The test instruments consisted of 40 items with options (a, b, c, d, e) that must be answered according to the answer key as respondents with the maximum score 1 and the minimum score 0 . The question items are designed to cover four cognitive regions according to Bloom's taxonomy $\mathrm{C}_{1}-\mathrm{C}_{4}$.
The steps taken to compile the test instrument are compiling the questionnaire, the items (items) and the testing instrument. Before testing, the instrument will be validated before hand to the expert validator. Furthermore, the instrument will be tested on students of class XII MIPA, because they have studied the material solubility product in class XI MIPA. Then, the results of the trials validity calculation, reliability, the level of difficulty of the questions, different power indexes, and distructors.

In addition, this study also used the non-test instrument in the form of an observation sheet. Observation sheet used to measure student activities during the learning process which takes place. Observations are carried out directly by the observer according to the prescribed scoring indicators and criteria.

\section{Results}

Based on the results of the analysis of validity, level of difficulty, power difference, distructor and reliability of the test instrument, the test instruments that can be used as data collection tools in this study are test instruments that meet valid criteria, have difficulty levels, test different power and conductors that meet the requirements and reliable. From the 23 valid questions obtained 20 questions that meet the requirements and 3 questions that do not meet the requirements. From the 20 questions that met the requirements, they were taken as research instruments.

The researcher prepared non-test instrument data analysis in the form of an observation sheet to evaluate the student activities which consisted of collaboration, seriousness, responsibility, asking and answering questions. Each indicator had 3 descriptors. The observation sheet of student activities used by researchers was adapted from the observation sheet of Naipospos (2016). So, the researcher did not validate the non-test instrument. The statistical data for student's activities learning outcome in the experimental group 1 and experimental group 11 are summarized in Table 1.

Data was analyzed by conducting normality test, homogeneity test, hypothesis test, and correlation test (Silitonga, 2011). The normality test is done to find out whether continuous data obtained is normally distributed or not. In this study, the normality test was carried out using the Chi Square test. Testing the normality of the data with the Chi Square $\left(X_{2}\right)$ test is done by comparing the standard/ standard (A) curve with the normal standard curve formed from the 
collected data (B). If $B$ is not significantly different from $A$, then it concluded that $B$ is normally distributed data. The calculation results for the normality test of the pretest and posttest data and student activities in the two groups are summarized in the Table 2 . Table 2 appears the pretest, posttest and the activities of the two experimental groups were normally distributed because $\left(\chi^{2}\right)_{\text {count }}<\left(\chi^{2}\right)_{\text {table }}$.

Table 1

Summary of descriptive statistics

\begin{tabular}{cccc}
\hline \multirow{2}{*}{ Data } & \multirow{2}{*}{ Statistic } & \multicolumn{2}{c}{ Group } \\
\cline { 3 - 4 } & & Exp 1 & Exp 11 \\
\hline \multirow{3}{*}{ Pretest } & Average & 36.83 & 35.50 \\
& SD & 10.63 & 10.12 \\
& Variance & 112.90 & 102.33 \\
& Average & 77.00 & 81.83 \\
Posttest & SD & 8.05 & 7.13 \\
& Variance & 64.83 & 50.83 \\
& Average & 78.15 & 82.96 \\
Activities & SD & 6.10 & 5.85 \\
& Variance & 37.15 & 34.17
\end{tabular}

Table 2

Data normality test

\begin{tabular}{lcccc}
\hline Group & Data & $\left.{ }^{2}\right)_{\text {count }}^{(\chi}$ & $\left.{ }^{2}\right)_{\text {table }}$ & Description \\
\hline \multirow{4}{*}{ Exp 1 } & Pretest & 6.85 & 11.07 & Normal \\
& Posttest & 8.55 & 11.07 & Normal \\
& Activities & 5.50 & 11.07 & Normal \\
& Pretest & 6.40 & 11.07 & Normal \\
Exp 11 & Posttest & 9.75 & 11.07 & Normal \\
& Activities & 6.40 & 11.07 & Normal \\
\hline
\end{tabular}

The homogeneity test was carried out to determine the level of dispersion of quantitative data or the homogeneity level of data in a group of data. In this case because the data used are from two groups of samples, the homogeneity testing is done through the $F$ Test. With the criteria if $\mathrm{F}_{\text {count }}<\mathrm{F}_{\text {table }}$ with $\alpha=0.05\left(\mathrm{db}=\left(\mathrm{n}_{1}-\mathrm{l}\right)\right.$ $\left.\left(n_{2}-1\right)\right)$ then the data is declared homogeneous. The calculation results for the homogeneity test of the pretest and posttest data and student activities in the two groups are summarized in the Table 3. Based on the Table 3, it appears that the pretest, posttest and student activities of the two experimental groups were homogeneous because $\mathrm{F}_{\text {count }}<\mathrm{F}_{\text {table }}$.

Table 3

Data homogeneity test

\begin{tabular}{ccccc}
\hline Group & Data & $\mathrm{F}_{\text {count }}$ & $\mathrm{F}_{\text {table }}$ & $\begin{array}{c}\text { Descriptio } \\
\mathbf{n}\end{array}$ \\
\hline \multirow{2}{*}{ Exp 1 } & Pretest & 1.10 & 1.86 & Homogen \\
& Posttest & 1.28 & 1.86 & Homogen \\
& Activities & 1.09 & 1.86 & Homogen \\
Exp 11 & Posttest & 1.28 & 1.86 & Homogen \\
& Activities & 1.09 & 1.86 & Homogen \\
\hline
\end{tabular}

The data are normally distributed and homogeneous. While, the hypothesis testing can be done by using the t-test statistical test, namely the two-party t-test and correlation test. The t-test of two parties to find out the differences in learning outcome and student activities. While, the correlation test to determine the relationship of activities and student learning outcome. This hypothesis test is used to find out whether the hypothesis in this study was accepted or rejected. The hypothesis testing whether the truth can be accepted or rejected, the $t$ test is used. The $t$ test used is a two-party $t$ test. The results of the testing hypothesis 1 and $\mathrm{ll}$ can be seen in Table 4 .

Based on the calculation of the two-party $t$ test, it is obtained $t_{\text {count }}=-2.452$. So that $t_{\text {count }}$ is in the critical area that is Ho reject with $t_{\text {count }}<-$ 2.002. The value of $t_{\text {count }}$ is negative because the average value of the experimental group 1 posttest is lower than the average value of the experimental group 11 posttest. Thus $\mathrm{Ho}$ is rejected, meaning there are differences in student learning outcome with PBL using macromedia flash handout on the solubility product constant $\left(K_{\mathrm{sp}}\right)$. Meanwhile, $\mathrm{t}$-test for activities, $\mathrm{t}_{\text {count }}=-3,123$. Thus, $t$ count is in the critical area that is Ho reject with $t_{\text {count }}<-2.002$. The value of $t_{\text {count }}$ is negative because the average value of the experimental group 1 activities is lower than the average value of the experimental group 11 activities. Thus, Ho is rejected, which means there are differences in student activities with PBL using 
macromedia flash and handout on the solubility product constant $\left(\mathrm{K}_{\mathrm{sp}}\right)$.

Table 4

Data hypothesis test of learning outcome

\begin{tabular}{|c|c|c|c|}
\hline Data & $t_{\text {count }}$ & $t_{\text {table }}$ & Description \\
\hline $\begin{array}{l}\text { Learning } \\
\text { outcome }\end{array}$ & -2.452 & 2.002 & $\begin{array}{l}\text { Ha accepted, } \\
\text { Ho rejected }\end{array}$ \\
\hline Activities & -3.123 & 2.002 & $\begin{array}{l}\text { Ha accepted, } \\
\text { Ho rejected }\end{array}$ \\
\hline
\end{tabular}

Table 5

Data correlation test

\begin{tabular}{llll}
\hline Group & $\mathbf{r}_{\text {count }}$ & $\mathbf{r}_{\text {table }}$ & Description \\
\hline Exp 1 & 0.625 & 0.361 & $\begin{array}{l}\text { Ha accepted, } \\
\text { Ho rejected }\end{array}$ \\
\hline Exp 11 & 0.683 & 0.361 & $\begin{array}{l}\text { Ha accepted, } \\
\text { Ho rejected }\end{array}$ \\
\hline
\end{tabular}

Correlation test is conducted to determine the relationship between learning outcome and student activities. Correlation test is done by comparing the $r$ value obtained $\left(r_{\text {count }}\right)$ with $r$ table at a certain level of significance, with the criteria: if $r_{\text {count }} \geq r_{\text {table }}$ then $\mathrm{Ho}$ is rejected. Results of hypothesis III testing can be seen in the the Table 5. From Table 5 obtained in the experimental group $1 r_{\text {count }}>r_{\text {table }}(0.625>0.361)$, it can be concluded that there is a positive correlation between activities and student learning outcome with PBL using Macromedia Flash on the solubility product constant $\left(\mathrm{K}_{\mathrm{sp}}\right)$. Whereas in the experimental group $1 \mathrm{ll} \mathrm{r}_{\text {count }}>r_{\text {table }}(0.683>0.361)$, it can be concluded that there is a positive correlation between student activities and learning outcome with the PBL using handout on the solubility product constant $\left(\mathrm{K}_{\mathrm{sp}}\right)$.

\section{Discussion}

PBL with the help of handout gave higher average learning outcome compared to PBL with the help of Macromedia flash, this was due to using media handout containing summaries of learning material given to each student can facilitate students' understanding in group discussions. Handout that students have can be read again when students repeat the lesson at home. Thus, the subject matter which already given can be remembered longer. While, learning using Macromedia flash is seen some students are quite interested in the media in the form of animation, but over time some students are less enthusiastic about paying attention to the material in the macromedia flash that is displayed through infocus in front of the group. At the beginning of learning, students are enthusiastic, but the learning students start to get bored at the end and chat outside the subject matter. In addition, the Macromedia flash displayed is not owned by each student, so students cannot repeat the subject matter with the media (Manalu et al. 2018; Manalu et al. 2018).

Student activities can be seen when learning activities take place. The PBL with a handout has the advantage that students can discuss seriously by solving problems (Harahap et al. 2018; Nasution et al. 2018). In addition, the material that is poorly understood by one group member, it can be helped by other group members who better understand by using handout. Thus, the students can also learn to communicate the knowledge that students have. Whereas in the group taught with PBL using Macromedia flash does not look like that, in this case, the students are less active. The students were less enthusiastic in paying attention to Macromedia flash during learning so that, they could not improve their understanding.

In this study, it can be concluded that PBL using handout is better than PBL with Macromedia flash both from learning outcome and student activities. This is in line with previous research, Agustina et al. (2013) in the results of their research showing that the use of media handout can improve student activities and achievements. Another study confirmed that PBL as an active learning approach have positive effects on higher learning achievement, overcoming alternative conceptions, and development some social skills (Tarhan \& AcarSesen, 2013). Teaching with problem solving approach also increase levels of critical thinking and self-directed learning (Shahin \& Tork, 2013).

The results showed that there is a positive correlation between learning activities and student learning outcome both experimental group 1 with PBL uses Macromedia flash and experimental group II with PBL using handout on the solubility product constant. This shows that student activities influence the magnitude of student learning outcome. Therefore, it is suggested that instructional methods promoting high level cognitive processing such as the PBL should be integrated into chemistry curriculum from middle to undergraduate level. The results support that if PBL is used in science classes more widely, it 
seems students could be achieve the skills that they need to be successful in their life.

\section{Conclusion}

Based on the results of data analysis, it can be concluded there was a difference in student's activities and learning outcome with PBL using macromedia flash and handout on the solubility product constant (Ksp). Meanwhile, there was a positive correlation between student's activities and learning outcome with PBL using macromedia flash and handout on the solubility product constant (Ksp).

\section{Acknowledgments}

The author would like to express the gratefulness to the Principal, Deputy Principal, Administrative Staff, Chemistry Teacher, and all students of Senior High School 9 Medan who have helped the author during the research process.

\section{References}

Adi, Y.K., Van-Hayus, E.S., \& Masykuri, M. (2014). Studi komparasi pembelajaran kooperatif tipe numbered heads together (nht) dilengkapi macromedia flash dan handout terhadap prestasi belajar siswa pada materi koloid kelas xi di sma n 1 karanganyar tahun ajaran 2012/2013. Jurnal Pendidikan Kimia, 3(2), 51-58.

Agustina, E., Saputro, A.N.C., \& Mulyani, S. (2013). Penggunaan metode pembelajaran jigsaw berbantuan handout untuk meningkatkan aktivitas dan prestasi belajar siswa pada materi pokok hidrokarbon kelas xc sma negeri 1 gubug tahun ajaran 2012/2013. Jurnal Pendidikan Kimia, 2(4), 66-7l.

Ariyanti, P., Martini, K.S., \& Setyowati, W.A.E. (2015). Penerapan problem based learning (pbl) dengan penilaian portofolio untuk meningkatkan keaktifan dan prestasi belajar pada materi stoikiometri di sman 2 surakarta tahun ajaran 2013/2014. Jurnal Pendidikan Kimia, 4(3), 1-9.

Arsyad, A. (2009). Media pembelajaran. Jakarta: PT RajaGrafindo Persada.

Aunurrahman. (2012). Belajar dan pembelajaran. Jakarta: Alfabeta.

Dewi, R.S., \& Utomo, S.B. (2013). Upaya peningkatan interaksi sosial dan prestasi belajar siswa dengan problem based learning pada pembelajaran kimia pokok bahasan sistem koloid di sma n 5 surakarta tahun pelajaran 2011/2012. Jurnal Pendidikan Kimia, 2(1), 15-20.
Duch, B.J., Groh, S.E., \& Allen, D.E. (2001). The power of problem-based learning: a practical" how to" for teaching undergraduate courses in any discipline. Stylus Publishing, LLC.

Flynn, A.B., \& Biggs, R. (2011). The development and implementation of a problem-based learning format in a fourth-year undergraduate synthetic organic and medicinal chemistry laboratory course. Journal of Chemical Education, 89(1), 52-57.

Harahap, N.M., Hutabarat, W., \& Silaban, S. (2018). The effect of model problem based learning (pbl) assistance of prezi media on student learning outcomes in colloid materials. Advances in Social Science, Education and Humanities Research, 200, 456-458.

Hutabarat, W., Sinaga, M., \& Silaban, S. (2017). Implementasi model problem based learning dalam perkuliahan daspen mipa prodi pendidikan kimia. Prosiding Seminar Hilirisasi Penelitian untuk Kesejahteraan Masyarakat, 384-388.

Manalu, H.C., Wartika, S., Hutabarat, W., \& Silaban, S. (2018). Implementasi media pembelajaran chemsdomino dalam meningkatkan hasil belajar kimia (pokok bahasan sistem periodik unsur). In Talenta Conference Series: Science and Technology $(S T), 1(3), 191-197$.

Manalu, H.C., Silaban, S., \& Hutabarat, W. (2018). The development of teaching materials stoichiometric integrated multimedia easy sketch. Advances in Social Science, Education and Humanities Research, 200, 352-356.

Mawarni, E., Mulyani, B., \& Yamtimah, S. (2015) Penerapan peer tutoring dilengkapi animasi macromedia flash dan handout untuk meningkatkan motivasi berprestasi dan prestasi belajar siswa kelas xi ipa 4 sman 6 surakarta tahun pelajaran 2013/2014 pada materi kelarutan dan hasil kali kelarutan. Jurnal Pendidikan Kimia, 4(1): 29-37.

Naipospos, F.A. (2016). Perbedaan hasil belajar dan aktivitas siswa yang diajarkan dengan problem based learning menggunakan real lab dan virtual chemlab pada materi titrasi asam dan basa. Skripsi. Medan: FMIPA Unimed.

Nasution, R., Silaban, S., \& Sudrajat, A. (2018). The influence of problem based learning, guided inquiry learning models assited by lectora inspire, and scientific attitudes to student's cognitive values. Advances in Social Science, Education and Humanities Research, 200, 265269. 
Nuryanto, N., Utami, B., \& Saputro, A.N.C. (2015). Penerapan model pembelajaran problem based learning (pbl) dilengkapi macromedia flash untuk meningkatkan kemampuan berpikir kritis dan prestasi belajar siswa pada materi pokok termokimia kelas xi siswa sma negeri 2 karanganyar tp 2014/2015. Jurnal Pendidikan Kimia, 4(4), 87-94.

Othman, H., Salleh, B.M., \& Sulaiman, A. (2014). An innovative learning cycle in problem-based learning. International Journal of Enhanced Research in Educational Development, 2(3), 5057.

Shahin, E.S., \& Tork,H.M. (2013). Critical thinking and self-directed learning as an outcome of problem-based learning among nursing students in Egypt and Kingdom of Saudi Arabia. Journal of Nursing Education and Practice, 3(12), 103.

Silitonga, P. M. (2011). Statistik Teori dan Aplikasi dalam Penelitian. Medan: FMIPA Unimed.

Silaban, S. (2017). Dasar-dasar pedidikan matematika dan ilmu pengetahuan alam. Medan: Harapan Cerdas Publisher.

Tarhan, L., \& Acar-Sesen, B. (2013). Problem based learning in acids and bases: learning achievements and students' beliefs. Journal of Baltic Science Education, 12(5), 565-578.

Wasonowati, R.R.T., Redjeki, T., \& Ariani, S.R.D. (2014). Penerapan model problem based learning ( $\mathrm{pbl}$ ) pada pembelajaran hukumhukum dasar kimia ditinjau dari aktivitas dan hasil belajar siswa kelas $\mathrm{x}$ ipa sma negeri 2 surakarta tahun pelajaran 2013/2014. Jurnal Pendidikan Kimia, 3(3), 66-75.

Wijaya, A.M., Suryani, N., \& Sudianto (2017). Digital media based on macromedia flash to increase the historical learning interest of senior high school students. American International Journal of Social Science, 6(2), 7177. 